\title{
ALTERNATIVE PEN HOUSING SYSTEM FOR FATTENING RABBITS : EFFECTS OF GROUP DENSITY AND LITTER
}

\author{
LAMBERTINI L., VignOLA G., ZAGHINI G.
}

\author{
Dipartimento di Scienze Veterinarie e Agroalimentari, Facoltà di Medicina Veterinaria, \\ V.le Crispi 212, 64100 TERAMO, Italy.
}

\begin{abstract}
The purpose of this experiment was to verify the compatibility of a group housing system, from weaning to slaughter, with the rabbit modern productive standards, evaluating the effects of different stocking densities and type of litter on health, performances and some aspects of carcass and meat quality. Two experiments were carried out. In the first, 184 rabbits were housed in two-places, either wire mesh cages $\left(16 / \mathrm{m}^{2}\right)$ or in $1.0 \mathrm{~m}^{2}$ pens on a straw litter at 2 densities ( 8 or 16 rabbits per $\mathrm{m}^{2}$ ); in the second experiment, 232 rabbits were housed in the same pens and at the same densities on either straw or wood shavings, while the control group was traditionally housed in cages of 2 rabbits. In experiment 1 , mortality rate was significantly higher for rabbits raised on litter at the higher density $(15.6 \%$ vs $4.2 \%$ and $7.5 \%$ for groups housed on litter at low density or in cages, respectively). Higher death incidence was mainly due to coccidiosis. Thus, a prophylactic treatment was provided to all the animals before the beginning of experiment 2 resulting in a lack of differences in mortality rate among the groups $(9.91 \%$ average). Rabbits housed in cages showed a significantly higher weight gain ( 41.0 vs 31.7 and $34 \mathrm{~g} / \mathrm{d}$ ) and a better feed efficiency than rabbits housed on litter in experiment 1 . On the contrary final live weight, daily weight gain and feed to gain ratio for caged animals were not significantly higher than for rabbits housed on litter in experiment 2. However, growth rate of rabbits kept at lower density was significantly higher than for the other animals reared in pens (33.2 vs $31.0 \mathrm{~g} / \mathrm{d}$ ), while the type of litter had no effects. Caged animals
\end{abstract}

showed a carcass weight and dressing out percentage significantly higher than all the other groups in the first experiment. Furthermore, the hot carcass weight among rabbits housed on litter was significantly higher for lower stocking density. In experiment 2, dressing out percentage was significantly better in caged rabbits $(57.4 \%)$ than in all the other experimental groups (55.1 to $55.8 \%)$. Moreover, carcass weight was significantly higher in rabbits kept at lower density than the others ones reared in pens $(P<0.05)$. The full gastrointestinal tract was significantly heavier in rabbits housed in pens on straw litter $(22.3 \%$ of live weight) in comparison with the caged animals $(18,7 \%)$. The chemical composition of the caecal content however did not show variation of the gross composition as a function of the litter type. In experiment 1 , the meat $\mathrm{pH}$ at $45 \mathrm{~min}$ and at $24 \mathrm{hrs}$ post mortem, as well as meat colour parameters were the same in all experimental groups. In experiment 2 , it can be observed that the hind leg weight was constant among the groups, while the muscle to bone ratio of the cut was significantly higher in caged than in all the other animals. Furthermore, rabbits on litter had on the whole meat with a higher water and a lower lipid content. In conclusion, group housing systems on litter implies some relevant questions that have to be pointed out, particularly concerning pathology problems (mainly connected to coccidiosis) compared to the intensive breeding in cages. Growth performances, slaughter results and carcass quality are on the whole better for animals traditionally raised in wire mesh cages.

RÉSUMÉ: Système alternatif en parc pour l'engraissement des lapins : effets de la densité et de la litière.

Le but de cette expérimentation a été de vérifier la compatibilité avec les standards actuels de production du lapin avec un système d'élevage en parcs sur litière, en tenant compte de l'effet de 2 densités et du type de litière sur la santé, les performances et les caractéristiques des carcasses et de la viande des lapins ainsi produits. Pour ce faire, deux essais successifs ont été entrepris avec un engraissement jusqu'à l'âge de 83 jours. Dans le premier, 184 lapins de 35 jours ont été répartis soit en cages grillagées de 2 sujets $\left(16 / \mathrm{m}^{2}\right)$, soit en parcs de $1 \mathrm{~m}^{2}$ pourvus de litière de paille à deux densités ( 8 ou 16 lapins par $\mathrm{m}^{2}$ ); dans le $2^{\text {eme }}$ essai, 232 lapins ont été logés soit dans des mêmes parcs aux 2 mêmes densités avec litière de paille ou de copeaux de bois, soit des cages grillagées par 2. Durant le premier essai, la mortalité s'est révélée significativement plus élevée pour le groupe de lapins à plus forte densité sur litière de paille $(15,6 \%$ contre $4,2 \%$ et $7,5 \%$ pour les autres lapins sur litière et en cages, respectivement). Sur litière, la mortalité était due principalement à de la coccidiose. Tous les animaux ont donc reçu un traitement anticoccidien avant le début du $2^{\text {eme }}$ essai (ainsi reporté à 42 jours). La mortalité entre 42 et 83 j a ensuite été similaire dans les parcs et dans les cages $(9,91 \%$ en moyenne). Les animaux élevés en cages par 2 ont eu une croissance et une efficacité alimentaire significativement plus favorable durant le premier essai (GMQ de 41,0 vs 31,7 et $34 \mathrm{~g} / \mathrm{j}$ ) ; ces mêmes paramètres se sont révélé similaires pour les deux systèmes d'élevage lors du $2^{\text {éme }}$

essai. Toutefois, la croissance des lapins élevés en parcs à $8 / \mathrm{m}^{2}$ s'est révélée significativement plus rapide que celle lapins logés à raison de $16 / \mathrm{m}^{2}(33,2$ vs $31,0 \mathrm{~g} / \mathrm{j})$; par contre, le type de litière n'a pas influencé de manière significative ces paramètres. Les caractéristiques bouchères (poids de carcasse chaude, rendement) ont toujours été meilleures chez les lapins élevés en cages (rendement à l'abattage de $57,4 \%$ vs 55,1 à $55,8 \%$ ). Le poids de carcasse a été significativement plus élevé à 8 lapins $/ \mathrm{m}^{2}$ qu'à 16 sujets $/ \mathrm{m}^{2}$. L'usage de la litière de paille a entraîné un accroissement du poids de l'appareil gastro-intestinal lors du premier essai $(22,3 \%$ contre $18,7 \%$ du poids vif dans les cages). Par contre, la composition chimique du contenu caecal a été similaire pour tous les lots dans le $2^{\text {eme }}$ essai. En ce qui concerne la qualité de la carcasse et de la viande, le rapport muscle/os a été meilleur pour les animaux en cage, et la viande des lapins élevés sur litière a présenté une teneur en eau plus élevé et une quantité de lipides plus faible. En conclusion, l'élevage de lapins en parcs sur litière comporte des difficultés de réalisation, en particulier liées à l'incidence de la coccidiose, à la durée accrue de la période d'engraissement et à l'utilisation efficace de l'espace. Les performances de croissance, les caractéristiques bouchères et la qualité des carcasses des lapins ainsi élevés sont, en général, inférieures à celles obtenues avec un élevage en cage.

\section{INTRODUCTION}

An increased interest towards a better protection of animal welfare conditions in zootechnical productions led to the promulgation of laws modifying intensive breeding technologies for some species.
In the near future the European Community legislation may consider and review meat rabbit production, questioning the intensive rearing system in cages.

Rabbit breeding in colonies could represent an interesting alternative to the classical cage. Previous researches pointed out that productive performance of rabbits reared on straw litter is comparable to the 
performance obtained with traditional cageing systems (CRIMELLA et al., 1988, 1990). Furthermore, the litter housing system reduces the cost of housing structures for the animals and it makes it easier to convert structures built for purposes other than rabbit breeding.

The group housing system and the wider spaces available should also better suit behavioural needs and welfare of the animals (FERRANTE et al., 1997; MORISSE and MAURICE, 1996). On the other side, aggressive behaviour and sanitary problems such as coccidiosis (GALLAZZI, 1985; BIGLER and OESTER, 1996) may partially affect the performance. However, ROMMERS and MEIJERHOF (1998) proved that at a stocking density of 17 animals per $\mathrm{m}^{2}$ no aggressive behaviour occurs until 11-12 weeks of life, independently from the group size (6 to 54 What?). The purpose of this experiment is to compare growth performance, health, carcass quality and some meat traits between caged and pen-raised rabbits. Effect of litter type and densities were also evaluated.

\section{MATERIALS AND METHODS}

The research was carried out according to an experimental design providing for two single experiments.

\section{Experiment 1}

The experiment took place in autumn in a farm equipped with an air control temperature system. A total of 184 commercial hybrid rabbits of both sexes, weaned at 35 days, were used. The rabbits were divided into 3 experimental groups, homogeneous in sex and weight, keeping separated females and males. The control group (TC) was housed in two-place cages (42 x $30 \mathrm{~cm}$, height $28 \mathrm{~cm}$ ). The other two groups (T1

Table 1 : Experimental design for experiment 1.

\begin{tabular}{c|c|c|c|c}
\hline $\begin{array}{c}\text { Group } \\
\text { s }\end{array}$ & Housing & Animals & Replicates & $\begin{array}{c}\text { Density } \\
\text { (animals/m }\end{array}$ \\
\hline T1 & Pen & 96 & 6 & 16 \\
T2 & Pen & 48 & 6 & $\mathbf{8}$ \\
TC & Cage & 40 & 20 & 16 \\
\hline
\end{tabular}

and T2) were reared in pens at different stocking densities as described in table 1 . The floor of the pens were constituted by a bottom layer of granular zeolite for collecting the leachate and by wheat straw litter, restored with fresh straw every day.

The 12 pens, each $1 \mathrm{~m}^{2}$ in surface $(100 \times 100 \mathrm{~cm})$, and separated by $70 \mathrm{~cm}$ high double wire netting, were set up in the same room as the cages. Every pen was equipped with 2 (T2) or 3 (T1) feeders (30 cm length) and with 2 (T2) or 3 (T1) nipple drinkers. All the animals received, ad libitum, water and a commercial pelleted feed [H2O: 11,41\%; crude protein $(\mathrm{N} \times 6.25)$ : $15,43 \%$; crude fat: $3,96 \%$; crude fibre: $15,99 \%$; ash: $6,48 \%$;] containing robenidine $(66 \mathrm{mg} / \mathrm{Kg})$. During the experiment the feed intake per replicate and the individual live weight were recorded every two weeks. At the end of the experiment, which lasted 48 days, all the rabbits ( 83 days old) were slaughtered without a preliminary period of fasting. For each animal the weight of the hot carcass (including head, liver, kidneys, scapular and perirenal fat, but thoracic offal excluded), of the skin and of the full gastrointestinal tract were recorded. Furthermore, on 30 carcasses, 10 for each group randomly chosen (half males and half females), we measured in situ the $\mathrm{pH}$ at 45 minutes and at 24 hours post mortem of the longissimus lumborum muscle, on the right side between the $6^{\text {th }}$ and the $7^{\text {th }}$ lumbar vertebra (OUHAYOUN and DALLE ZOTTE, 1996). Finally, on a transversal section of the same opposite muscle, the colour parameters $\left(\mathrm{L}^{*}, \mathrm{a}^{*}, \mathrm{~b}^{*}\right.$, Hue and Chroma) were estimated with a portable colorimeter Hunterlab MiniScan $/ \mathrm{XE}^{\mathrm{TM}}$, using the CIELab method (OUHAYOUN and DALLE ZOTTE, 1996). All the animals that died during the experiments underwent anatomo-pathological examination to assess the probable death causes.

\section{Experiment 2}

In the second experiment 232 rabbits (half males and half females), differing from those of experiment 1 for their genetic commercial line, were weaned at 35 days of age. The experiment was carried out in the same farm building as experiment 1 . Because of the high occurrence of coccidiosis during experiment 1 , before the beginning of the assay all the animalsreceived a pharmacological prophylactic
Table 2 : Experimental design for experiment 2

\begin{tabular}{c|c|c|c|c|c}
\hline $\begin{array}{c}\text { Group } \\
\text { s }\end{array}$ & Housing & Animals & Replicates & Litter & $\begin{array}{c}\text { Density } \\
\text { (animals/m }\end{array}$ \\
\hline T1 & Pen & 64 & 4 & wood shaving & 16 \\
T2 & Pen & 32 & 4 & wood shaving & 8 \\
T3 & Pen & 64 & 4 & Straw & 16 \\
T4 & Pen & 32 & 4 & Straw & 8 \\
TC & Cage & 40 & 20 & - & 16 \\
\hline
\end{tabular}

treatment composed of trimethoprim $(4 \mathrm{~g} / 100 \mathrm{ml})$ and sodium sulphadymetoxin $(21.42 \mathrm{~g} / 100 \mathrm{ml})$. For 5 days, the product was dissolved in the drinking water at a concentration of $0.5 \mathrm{ml} / 1$. Subsequently, the rabbits, 42 days old, were divided into the following experimental groups, according to the same criteria adopted in experiment 1 : 
Table 3 : Effects of housing system on growth performances (mean values) (Exp. 1).

\begin{tabular}{l|c|c|c|c|c|c}
\hline \multicolumn{2}{c|}{ Parameters } & $\begin{array}{c}\text { Live weight } \\
\text { at start } \\
(\mathbf{g})\end{array}$ & $\begin{array}{c}\text { Slaughter } \\
\text { weight } \\
(\mathbf{g})\end{array}$ & $\begin{array}{c}\text { Daily } \\
\text { weight gain } \\
(\mathbf{g} / \mathbf{d a y})\end{array}$ & $\begin{array}{c}\text { Feed } \\
\text { intake } \\
(\mathbf{g} / \mathbf{d a y})\end{array}$ & $\begin{array}{c}\text { Feed } \\
\text { to } \\
\text { gain ratio }\end{array}$ \\
\hline & $\mathrm{T} 1$ & 854 & $2372^{\mathrm{B}}$ & $317^{\mathrm{B}}$ & $114.0^{\mathrm{B}}$ & $3.63^{\mathrm{A}}$ \\
\hline Housing system & $\mathrm{T} 2$ & 854 & $2487^{\mathrm{B}}$ & $34.0^{\mathrm{B}}$ & $121.1^{\mathrm{B}}$ & $3.57^{\mathrm{A}}$ \\
\hline Residual SD & $\mathrm{TC}$ & 854 & $2817^{\mathrm{A}}$ & $41.0^{\mathrm{A}}$ & $138.5^{\mathrm{A}}$ & $3.37^{\mathrm{B}}$ \\
\hline Statistical significance (P) & 0.999 & $<0.0001$ & $<\mathbf{0 . 0 0 0 1}$ & $<\mathbf{0 . 0 0 0 1}$ & 0.40 \\
\hline
\end{tabular}

${ }^{A}, B$ : means within the same column without a common superscript differ significantly at $\mathrm{P}=0.05$

In 8 of the 16 pens the litter was made of wood shavings, while in the other ones it was made of wheat straw. All the animals received, ad libitum, drinking water and the same pelleted feed used for experiment 1. During the 39 days of the experiment and at slaughter, the same parameters of experiment 1 were recorded. Furthermore, on 48 animals chosen at random among the experimental groups, the full gastrointestinal tract was weighed and a sample of the caecal content was examined to assess possible modifications of its chemical composition due to litter straw consumption. Finally, from the 48 carcasses of the same rabbits, the left hind leg was dissected and its bones were separated from the meat (BLASCO and OUHAYOUN, 1993). The chemical composition of the latter was determined.

All the data were analysed according to the GLM procedure of the SAS statistical package (SAS, 1989). The model included the effects of treatment and sex (without interaction because not significant).
Furthermore, in experiment 2, data were analysed according to a variance analysis including pertinent contrasts to evaluate the effects of density and litter type. The differences between males and females were not significant and are consequently not reported in the tables. When the $F$ test analysis of variance was significant $(\mathrm{P}<0.05)$, differences among means were compared using the SNK test. Mortality rate among the different groups was compared using the $\chi^{2}$ test (CAMUSSI et al., 1981).

\section{RESULTS}

In the first experiment the average mortality was $10.87 \%$, with different incidence among the experimental groups. In particular the number of dead rabbits was respectively $15(15.6 \%), 2(4.2 \%)$ and 3 (7.5\%) for groups $\mathrm{T} 1, \mathrm{~T} 2$ and $\mathrm{TC}$, with significant differences between groups $\mathrm{T} 1$ and $\mathrm{T} 2 \quad \chi^{2}=5.61$;

Table 4 : Effects of housing system, density and litter on growth performances (mean values)

(Exp. 2).

\begin{tabular}{|c|c|c|c|c|c|c|}
\hline \multicolumn{2}{|c|}{ Parameters } & $\begin{array}{l}\text { Live weight } \\
\text { at start }(\mathrm{g})\left({ }^{1}\right)\end{array}$ & $\begin{array}{l}\text { Slaughter } \\
\text { weight (g) }\end{array}$ & $\begin{array}{c}\text { Daily weight } \\
\text { gain (g) }\end{array}$ & $\begin{array}{c}\text { Feed intake } \\
(\mathrm{g} / \mathrm{dav})\end{array}$ & Feed to gain \\
\hline \multirow{5}{*}{ Housing system } & $\mathrm{T} 1$ & 1202 & 2410 & 31.2 & 121.0 & 3.60 \\
\hline & $\mathrm{T} 2$ & 1202 & 2496 & 33.1 & 115.3 & 3.53 \\
\hline & T3 & 1197 & 2392 & 30.8 & 121.5 & 3.66 \\
\hline & $\mathrm{T} 4$ & 1199 & 2490 & 33.3 & 120.1 & 3.46 \\
\hline & TC & 1202 & 2531 & 34.1 & 128.0 & 3.80 \\
\hline \multirow{2}{*}{ Density } & $16 / \mathrm{m}^{2}$ & 1199 & $2401^{\mathrm{B}}$ & $31.0^{\mathrm{B}}$ & 121.2 & 3.63 \\
\hline & $8 / \mathrm{m}^{2}$ & 1200 & $2493^{\mathrm{A}^{-1}}$ & $33.2^{\mathrm{A}}$ & 117.7 & 3.49 \\
\hline \multirow{2}{*}{ L.itter } & wood shaving & 1202 & 2440 & 31.8 & 118.2 & 3.57 \\
\hline & straw & 1197 & 2425 & 31.6 & 120.8 & 3.56 \\
\hline \multicolumn{2}{|l|}{ Residual SD } & 127 & 260 & 5.9 & 9.4 & 0.29 \\
\hline \multirow{3}{*}{$\begin{array}{l}\text { Statistical } \\
\text { significance }(\mathrm{P})\end{array}$} & Housing & 0.999 & 0.053 & 0.059 & 0.127 & 0.226 \\
\hline & Density & 0.965 & 0.026 & 0.019 & 0.443 & 0.354 \\
\hline & Litter & 0.837 & 0.796 & 0.972 & 0.560 & 0.939 \\
\hline
\end{tabular}

A. B. means within the same column without a common superscript differ significantly;

(') at 42 days. 
Table 5 : Effects of housing system on slaughtering data (mean values) (Exp. 1).

\begin{tabular}{c|c|c|c|c|c}
\hline \multicolumn{2}{|c|}{ Parameters } & $\begin{array}{c}\text { Hot carcass } \\
\text { weight (g) }\end{array}$ & $\begin{array}{c}\text { Dressing out } \\
\text { percentage (\%) }\end{array}$ & $\begin{array}{c}\text { Skin weight ( } \\
(\%)\end{array}$ & $\begin{array}{c}\text { Full gastrointestinal } \\
\text { tract weight (1) } \\
(\%)\end{array}$ \\
\hline \multirow{2}{*}{ Housing system } & $\mathrm{T} 1$ & $1312^{\mathrm{C}}$ & $55.1^{\mathrm{B}}$ & $9.3^{\mathrm{B}}$ & $22.8^{\mathrm{A}}$ \\
\cline { 2 - 6 } & $\mathrm{T} 2$ & $1398^{\mathrm{B}}$ & $56.0^{\mathrm{B}}$ & $9.6^{\mathrm{B}}$ & $21.8^{\mathrm{A}}$ \\
\hline Residual SD & $1640^{\mathrm{A}}$ & $58.2^{\mathrm{A}}$ & $10.8^{\mathrm{A}}$ & $18.7^{\mathrm{B}}$ \\
\hline Statistical significance (P) & 203 & 2.5 & 1.1 & 2.9 \\
\hline
\end{tabular}

$\left(^{1}\right)$ on live weight. ${ }^{A, B}$ : means within the same column without a common superscript differ significantly.

$\mathbf{P}<0.05$ ). Anatomopathological features showed typical lesions from coccidiosis to be the cause of death for all the rabbits housed on litter ( $\mathrm{T} 1$ and $\mathrm{T} 2$ ), while dead animals in group TC showed lesion due to respiratory pathologies. In the second experiment the mortality was not meaningfully different among the experimental groups $(\mathrm{T} 1=10.9 \% ; \mathrm{T} 2=6.2 \%$; $\mathrm{T} 3=12.5 \%$; $\mathrm{T} 4=9.4 \%$; $\mathrm{TC}=7.5 \%)\left(\chi^{2}=1.31 ; \mathrm{n} . \mathrm{s}.\right)$, even though the average value was similar to the $1^{\text {st }}$ experiment $(9.91 \%)$. Anatomopathological features did not show lesions due to coccidiosis in any of the dead rabbits, independently from the experimental group.

In the first experiment, rabbits housed in cages (TC) showed a significantly higher weight gain than rabbits housed on litter (Table 3), while no difference was observed between the two groups on litter (T1 vs T2). Consequently, the slaughtering weight for rabbits in cages were higher than in the other groups
$(\mathbf{P}<0.001)$. Furthermore, animals on litter consumed a considerably lower amount of feed $(-17.7 \%$ and $12.5 \%$ per $\mathrm{T} 1$ and $\mathrm{T} 2$ respectively) but showed a worse feed efficiency than the ones in cages $(P<0.001)$.

In experiment 2, the final live weight and the daily weight gain of caged animals (TC) were not significantly higher than for rabbits housed on litter (Table 4). However, growing performances for rabbits kept at lower density were significantly higher than for the other animals reared in pens $(P<0.05)$, while the type of litter had no effects. Feed intake and feed to gain ratio had similar values among all the experimental groups.

In experiment 1, animals in cages (TC) showed better slaughter performances (Table 5), with carcass weight and dressing out percentages significantly higher than in the other groups $(\mathrm{P}<0.001)$. It has to be pointed out that the hot carcass weight was different

Table 6 : Effects of housing system, density and litter on slaughtering data and chemical composition of caecal content (mean values) (Exp. 2).

\begin{tabular}{|c|c|c|c|c|c|c|c|c|c|}
\hline \multirow{2}{*}{\multicolumn{2}{|c|}{ Parameters }} & \multirow{3}{*}{$\begin{array}{c}\begin{array}{c}\text { Hot } \\
\text { carcass } \\
\text { weight }(\mathrm{g})\end{array} \\
1328^{\mathrm{B}} \\
\end{array}$} & \multirow{3}{*}{$\begin{array}{c}\begin{array}{c}\text { Dressing out } \\
\text { percentage } \\
(\%)\end{array} \\
55.1^{\mathrm{B}} \\
\end{array}$} & \multirow{3}{*}{$\begin{array}{c}\begin{array}{c}\text { Drip loss } \\
(\%)\end{array} \\
1.68 \\
\end{array}$} & \multicolumn{5}{|c|}{ Caecal content $(\%)$} \\
\hline & & & & & Dry & Crude & NDF & ADF & AnI \\
\hline \multirow{5}{*}{$\begin{array}{l}\text { Housing } \\
\text { system }\end{array}$} & $\mathrm{T} 1$ & & & & 23.0 & 24.5 & 38.1 & 28.3 & 6.3 \\
\hline & $\mathrm{T} 2$ & $1383^{\mathrm{AB}}$ & $55.4^{\mathrm{B}}$ & 1.71 & 22.1 & 25.2 & 37.6 & 28.2 & 6.5 \\
\hline & $\mathrm{T} 3$ & $1352^{\mathrm{B}}$ & $55.8^{\mathrm{B}}$ & 1.82 & 22.3 & 24.9 & 39.4 & 27.9 & 5.6 \\
\hline & $\mathrm{T} 4$ & $1399^{\mathrm{AB}}$ & $55.2^{\mathrm{B}}$ & 1.84 & 21.7 & 24.2 & 39.3 & 28.8 & 5.7 \\
\hline & $\mathrm{TC}$ & $1452^{\mathrm{A}^{-}}$ & $57.4^{\mathrm{A}}$ & 1.59 & 24.5 & 24.8 & 38.2 & 28.4 & 6.8 \\
\hline \multirow{2}{*}{ Density } & $16 / \mathrm{m}^{2}$ & $1340^{B}$ & 55.4 & 1.75 & 22.6 & 24.7 & 38.7 & 28.1 & 5.9 \\
\hline & $8 / \mathrm{m}^{2}$ & $1391^{\mathrm{A}}$ & 55.3 & 1.77 & 21.9 & 24.7 & 38.4 & 28.5 & 6.1 \\
\hline \multirow{2}{*}{ Litter } & wood shaving & 1355 & 55.2 & 1.69 & 22.5 & 24.8 & 37.8 & 28.2 & 6.4 \\
\hline & straw & 1375 & 55.5 & 1.83 & 22.0 & 24.6 & 39.3 & 28.4 & 5.6 \\
\hline \multicolumn{2}{|c|}{ Residual SD } & 144 & 1.8 & 0.50 & 2.6 & 2.3 & 3.2 & 2.4 & 1.1 \\
\hline \multirow{3}{*}{$\begin{array}{l}\text { Statistical } \\
\text { significance } \\
\text { (P) }\end{array}$} & Housing & 0.0016 & $<0.0001$ & 0.187 & 0.126 & 0.925 & 0.778 & 0.974 & 0.066 \\
\hline & Density & 0.027 & 0.468 & 0.094 & 0.428 & 0.936 & 0.811 & 0.638 & 0.634 \\
\hline & Litter & 0.368 & 0.323 & 0.738 & 0.572 & 0.736 & 0.188 & 0.900 & 0.057 \\
\hline
\end{tabular}

$A, B$ : means within the same column without a common superscript differ significantly. 
Table 7 : Effects of housing system on meat pH and colour parameters (') (mean values) (Exp. 1).

\begin{tabular}{|c|c|c|c|c|c|c|c|c|c|}
\hline \multirow{2}{*}{\multicolumn{2}{|c|}{ Parameters }} & \multirow{2}{*}{$\mathbf{p H}_{1}$} & \multirow{2}{*}{$\mathbf{p H}_{2}$} & \multirow{2}{*}{$\mathbf{p H}_{1}-\mathbf{p H}_{\mathbf{2}}$} & \multicolumn{5}{|c|}{ Colour parameters } \\
\hline & & & & & $\mathbf{L}$ & $\mathbf{a}$ & b & $C^{*}$ & $\mathbf{H}^{0}$ \\
\hline \multirow{3}{*}{ Housing system } & $\mathrm{T} 1$ & 7.07 & 6.00 & 1.07 & 45.53 & -3.68 & 0.76 & 3.81 & -0.19 \\
\hline & $\mathrm{T} 2$ & 7.00 & 5.99 & 1.07 & 46.56 & -3.67 & 0.74 & 3.93 & -0.16 \\
\hline & $\mathrm{TC}$ & 7.12 & 6.14 & 0.98 & 46.77 & -3.72 & 0.61 & 3.82 & -0.16 \\
\hline \multicolumn{2}{|c|}{ Residual SD } & 0.18 & 0.20 & 0.29 & 3.27 & 0.27 & 1.00 & 0.48 & 0.23 \\
\hline \multicolumn{2}{|c|}{ Statistical significance $(\mathrm{P})$} & 0.401 & 0.056 & 0.324 & 0.702 & 0.916 & 0.977 & 0.836 & 0.987 \\
\hline
\end{tabular}

(1) On longissimus lumborum cross section.

The weight of the full gastrointestinal tract was significantly higher for rabbits housed on litter ( $\mathrm{T} 1$ and T2 vs TC).

Also in experiment 2 the carcass weight turned out to be higher for rabbits in cages rather than on litter only at the highest density (TC vs $\mathrm{T} 1$ and $\mathrm{T} 3$ ) while dressing out percentage was better than all the other experimental groups $(\mathrm{P}<0.001)$ (Table 6). Furthermore, we observed differences in carcass weight as a function of stocking density: this parameter was significantly higher in rabbits kept at lower density than the others ones reared in pens $(\mathrm{P}<0.05)$. The chemical composition of the caecal content (Table 6) did not show significant variation, not even for the fibre composition as a function of the litter type (wood vs straw). Some meat quality data measured during the

Table 8 : Effects of housing system, density and litter on meat to bone ratio and chemical composition of meat hind leg (mean values) (Exp. 2).

\begin{tabular}{|c|c|c|c|c|c|c|}
\hline \multirow{2}{*}{\multicolumn{2}{|c|}{ Parameters }} & \multirow{3}{*}{$\begin{array}{c}\begin{array}{c}\text { Hind leg } \\
\text { weight } \\
\text { (g) }\end{array} \\
194.7 \\
\end{array}$} & \multirow{3}{*}{$\begin{array}{c}\text { Meat } \\
\text { to } \\
\text { bone } \\
\text { ratio } \\
4.43^{\mathrm{B}} \\
\end{array}$} & \multicolumn{3}{|c|}{ Meat composition } \\
\hline & & & & \multirow{2}{*}{$\begin{array}{c}\begin{array}{c}\text { Dry } \\
\text { matter } \\
(\%)\end{array} \\
26.1^{\mathrm{B}}\end{array}$} & \multirow{2}{*}{$\begin{array}{c}\begin{array}{c}\text { Crude } \\
\text { protein } \\
\text { (\% d.m.) }\end{array} \\
84.2^{\mathrm{A}}\end{array}$} & \multirow{2}{*}{$\begin{array}{c}\begin{array}{c}\text { Crude } \\
\text { fat } \\
\text { (\% d.m.) }\end{array} \\
9.7^{\mathrm{B}} \\
\end{array}$} \\
\hline \multirow{5}{*}{ Housing system } & $\mathrm{T} 1$ & & & & & \\
\hline & $\mathrm{T} 2$ & 196.8 & $4.37^{8}$ & $26.9^{A B}$ & $81.4^{\mathrm{AB}}$ & $13.3^{\mathrm{AB}}$ \\
\hline & T3 & 207.0 & $4.50^{\mathrm{B}}$ & $26.1^{\mathrm{B}}$ & $82.8^{\mathrm{AB}}$ & $10.6^{\mathrm{B}}$ \\
\hline & T4 & 190.4 & $4.44^{\mathrm{B}}$ & $26.6^{\mathrm{AB}}$ & $84.3^{A}$ & $10.5^{\mathrm{B}}$ \\
\hline & $\mathrm{TC}$ & 205.0 & $5.04^{\mathrm{A}}$ & $27.4^{\mathrm{A}}$ & $80.5^{\mathrm{B}}$ & $14.2^{\mathrm{A}}$ \\
\hline \multirow{2}{*}{ Density } & $16 / \mathrm{m}^{2}$ & 200.9 & 4.46 & $26.1^{\mathrm{B}}$ & 83.6 & 10.2 \\
\hline & & 193.6 & 4.41 & $26.7^{\mathrm{A}}$ & 82.8 & 11.9 \\
\hline Litter & $\begin{array}{c}\text { wood shaving } \\
\text { straw }\end{array}$ & $\begin{array}{l}195.8 \\
198.7\end{array}$ & $\begin{array}{l}4.40 \\
4.47\end{array}$ & $\begin{array}{l}26.5 \\
26.3\end{array}$ & $\begin{array}{l}82.8 \\
83.6\end{array}$ & $\begin{array}{l}11.5 \\
10.6\end{array}$ \\
\hline Residual SD & & 13.9 & 0.42 & 0.85 & 2.7 & 2.7 \\
\hline \multirow{3}{*}{$\begin{array}{l}\text { Statistical } \\
\text { significance }(\mathrm{P})\end{array}$} & Housing & 0.116 & 0.003 & 0.008 & 0.008 & 0.002 \\
\hline & Density & 0.561 & 0.637 & 0.046 & 0.470 & 0.084 \\
\hline & Litter & 0.149 & 0.709 & 0.495 & 0.434 & 0.339 \\
\hline
\end{tabular}

\footnotetext{
$\mathrm{A}, \mathrm{B}$ : means within the same column without a common superscript differ significantly
}

first experiment are illustrated in Table 7. The $\mathrm{pH}$ at 45 $\min$. and at $24 \mathrm{hrs}$ post mortem, as well as the $\mathrm{pH}$ drop, did not show any difference connected with the housing system. Also lean colour parameters were the same for the three experimental groups.

From data shown in Table 8, which refers to experiment 2 , it can be observed that the hind leg weight was constant among the groups, while the muscle to bone ratio of the cut was significantly higher in group TC (caged) than in all the other groups. Also, the chemical composition of the meat was dependent on the housing system, in that rabbits on litter at higher densities had meat with a higher water content $(P<0.05)$. Crude fat percentage was lower in group housed-rabbits than in caged ones, except T2. On the other hand, protein content was on the whole higher in rabbits on litter, even if differences were significant only between $\mathrm{T} 1$ and $\mathrm{T} 4 \mathrm{vs} \mathrm{TC}$.

\section{DISCUSSION}

The high occurrence of coccidiosis observed in rabbits from groups $\mathrm{T} 1$ and $\mathrm{T} 2$ (litter) during experiment 1 points out that this pathology represents the most serious drawback of the litter housing system.

Robenidine supplied with the feed at a dosage allowed by the current legislation $(66 \mathrm{mg} / \mathrm{kg})$ was in fact not effective to limit the negative effects of the pathology.

Previous research (GALlazZI, 1985; GALLAZZI and ARRIGH, 1988) already pointed out the issue, with particular attention to the final breeding phase, underlining the need of repeated pharmacological treatments to 
control the occurrence of the disease.

The treatment provided to the animals before the beginning of experiment 2 proved effective in controlling the enteric pathology due to coccidia throughout the fattening period.

The final live weight of animals housed in cages was similar to that obtained by rabbits simultaneously reared in the same farm and it was in relationship with the slaughtering age and genetic type difference between the two experiments. The productive performance in vivo between caged and pen housed rabbits in the two experiments may seem contradictory if the analysis does not account for the enteric pathology that occurred during experiment 1 . We believe that even therabbits that completed the fattening period, coccidiosis caused a worse health condition, thus being the primary cause of the diminished production observed for animals on litter, in experiment 1. Other reasons can not be excluded, such as the different extent of movement allowed and the lower feed intake for animals on litter, which ate straw whose consumption could not be measured. On the other hand, the lack of significant differences in growth performances observed between rabbits kept on wood shaving or straw in experiment 2 scales down the influence of the latter variable. On the contrary, the highest density seems to reduce growth performances of rabbits reared in pens compared with caged ones ( $\mathrm{Tl}$ and $\mathrm{T} 3$ vs TC), even if differences did not reach a significant level $(P<0.059)$. Also MAERTENS and VAN HERCK (2000) reported that rabbits bred in pens on a wire grid floor at the same density $\left(15.5 / \mathrm{m}^{2}\right)$ showed lower production results than rabbits housed in classical cages.

Furthermore, considering only the rabbits housed in pens in experiment 2 , the different stocking density (8 vs 16 animals $/ \mathrm{m} 2$ ) had significant effects on growth, but not on feed intake and feed efficiency. The wider spaces available to the animals on litter, likely creating a condition of increased comfort, probably led to a greater expression of the productive potential of the rabbits, according to what has been observed by others(FERRANTE et al., 1996).

Differently from what was noted by GALLAZZI (1985), we did not observe any aggressive outburst among males that could affect experimental results or suggest the need to move the animals to a cage after the $59^{\text {th }}$ day of life, as recommended by CRIMELLA et al. (1990).

Previous research demonstrated that aggressive behaviour increases in frequency from the $75^{\text {th }}$ to the $84^{\text {th }}$ day of life, but at a higher live weight than reached in our experiment (BIGLER and OESTER, 1996). Moreover, the seriousness of injuries seems to be related to group size (BIGLER and OESTER, 1996).

ROMMERS and MEIJERHOF (1998) reached similar conclusions, but they do not give any importance to the density variable. These authors worked with a density of 17 animals per $\mathrm{m}^{2}$ of cage surface, similar to that we used and considered optimal by MORISSE and MAURICE (1997). It is also possible that the lack of aggressivness among males was caused by the short photoperiod in the season when our experiments were carried out (autumn-winter)

At slaughter the caged animals had better production results in both the experiments, with significantly higher dressing out percentages than in all the other experimental groups. As known, the trend of this parameter is affected by the weight incidence of the gastrointestinal tract and the skin as a percentage of the live weight. In experiment 1 , the full gastrointestinal tract turned out to be significantly heavier in rabbits housed in pens on straw litter, in comparison with the caged animals (Table 5). In MORISSE et al. (1999), rabbits housed on straw litter were occasionally observed gnawing and/or ingesting small amounts of straw. It is possible that a different degree of "filling up" of the gastrointestinal tract was due to ingestion of the litter. On the other hand, as the whole organism grows, the incidence of the carcass on the live weight increases physiologically, as the weight of the gastrointestinal tract (as a percentage) decreases. The allometry coefficient of the digestive system is in fact below 1 (CANTIER et al., 1969). It is therefore possible that the trend in dressing percentage was caused by both the "filling up" of the digestive tract and physiological factors. In the second experiment, in fact, this parameter was almost the same for rabbits housed on straw litter ( $\mathrm{T} 1$ and $\mathrm{T} 2$ ) and on woodshaving litter (T3 and T4) (table 6).

The chemical composition of the caecal contents did not present significant differences ascribed to the treatments, also for the fibrous components. The matter that is carried back to this tract of the digestive system by the antiperistaltic action of the proximal colon determines the caecal content characteristics. This particular aspect in the rabbit digestive physiology is differently stimulated by the feed particle size (BOUYSSOU et al., 1988). GIDENNE (1993) demonstrated that only particles smaller than $0.315 \mathrm{~mm}$ in diameter are carried back to the caecum, while the rest is eliminated with the hard facces. The evidence demonstrates that structural carbohydrates, ingested along with the litter, were not recycled in the caecum, likely because of their particle size, and thus they should only have a "ballast" effect .

Differently from what was expected, the housing system did not affect $\mathrm{pH}$ and meat colour. In the pig, ESSEN-GUSTAVSSON et al., (1988) observed a greater accumulation of muscular glycogen, with consequent lower $\mathrm{pH}$, in animals that underwent moderate physical exercise. The higher final live weight in caged rabbits did not produce a higher muscle $\mathrm{pH}$. Thus the trend towards a lower meat acidification in heavier animals, 
observed by HULOT and OUHAYOUN (1999) in a recent review, did not occur. Accordingly, the pen housing system does not seem to modify meaningfully meat colour parameters, tightly correlated to $\mathrm{pH}$.

Housing system, density or litter type did not influence the hind leg weight, while the muscle to bone ratio was significantly higher in caged animals. The housing system and the density also modified the chemical composition of the meat: on the whole the rabbits on litter were leaner with a higher water and protein content and lower in lipids. The lower exercise possibility for the caged animals could have produced the observed modifications, while it is less clear what caused differences among the animals in pens. It can be hypothesised, though, that the result was simply due to the different corporal growth level reached at the end of the experiment, even if effects of the interaction among animals cannot be excluded.

\section{CONCLUSIONS}

On pen reared rabbits, the type of litter does not seem to influence the performances, while the animals housed at lower density grow better.

However, the group housing system on litter, usually believed more respectful of rabbit welfare, imply some relevant questions that have to be pointed out.

In particular, pathology problems related with litter clearly occurred in experiment 1 . Thus a strict and routinely pharmacological control of enteric pathologies should be supplied to limit sanitary problems connected mainly to coccidiosis.

Furthermore group rearing of rabbits, independently from the type of litter, could produce a longer production cycle and a less efficient use of space, compared to the intensive breeding in cages.

Finally, growth performances, slaughter results and carcass quality are on the whole better for animals traditionally caged.

Acknowledgments: a special thank to Miss Elisabetta Lambertini and Dr. Maria Cristina Benassi for their patient collaboration in the redaction of the present manuscript.

Received : May $30^{\text {th }}, 2001$

Accepted : December $19^{\text {th }}, 2001$

\section{REFERENCES}

Bigler L., Oester H., 1996. Group housing for male rabbits. Proc. of $6^{\text {th }}$ World Rabbit Congress, vol.2, 11-415.

BLASCO A., OUHAYOUN J., 1993. Harmonisation of criteria and terminology in rabbit meat research. Revised proposal. World Rabbit Sci., 4, 93-98.

Bouyssou T., Candau M., Ruckebusch Y., 1988. Réponses motrices du colon aux constituants pariétaux et à la finesse de mouture des aliments chez le lapin, Reprod. Nutr. Dévelop., 28, 181-182.

Camussi A., Moller F., Ottaviano E., Sari Gorla M., 1981. Metodi statistici per la sperimentazione biologica. Zanichelli (ed), Bologna.

Cantier J., Vezinhet A., Rouvier R., Dauzier L., 1969. Allométrie de croissance chez le lapin (Oryctolagus cuniculus). Ann. Biol. Anim. Bioch. Biophys., 9, 5-39.

CRIMElla C., LuZi F., AMBoINI M., 1990. Sistemi altemativi per la stabulazione del coniglio da carne. Riv. Coniglicoltura, 27 (I), $39-42$.

Crimella C., Verga M., Luzi F., Canali E., 1988. Sistema di allevamento alternativo nell'ingrasso del coniglio. Riv. Coniglicoltura, 25 (2), 41-44.

EssÉn-GustavsSON B., LundSTROM K., LARSSON G., LindHOLM A., Nordin A.C., Hansson I., ToRnBERg E., 1988. The effect during growth of moderate exercise on muscle metabolic characteristics in vivo and relation to meat quality and sensory properties. Proc $34^{\text {th }}$ Int. Congress Meat Sci. Technol., 27-30

Ferrante V., Canali E., Mattiello S., Verga M., 1997 Allevamento del coniglio a terra: effetto della densità. Proc. of XII Congresso Nazionale A.S.P.A., 385-386.

GALLAZZI D., 1985. Allevamento e svezzamento del coniglio su lettiera permanente. Riv. Coniglicoltura, 22 (12), 36-38.

GALlAZZI D., ARRIGHI P., 1988. Allevamento del coniglio su lettiera permanente. Aspetti sanitari. Riv. Coniglicoltura, 25 (2), 49-53.

GIDENNE T., 1993. Measurement of the rate of passage in restricted-fed rabbits: effect of dietary cell wall level on the transit of fibre particles of different size, Anim. Feed Sci. Technol., 42, 151-163.

Huzot F., OUHAYOUN J., 1999. Muscular pH and related traits in rabbit: a review, World Rabbit Sci., 7, 15-36.

MaERTENS L., VAN HerCK A., 2000. Performances of weaned rabbits raised in pens or in classical cages. First results. Proc. $7^{\text {th }}$ World Rabbit Congress, vol. B, 435-440

Morisse J.P., Bollletot E., MARTREnCHAR A., 1999. Preference testing in intensively kept meat production rabbit for straw on wire grid floor. Applied Anim. Behav. Sci., 64, 71-80.

MORISSE J.P., MAURICE R., 1997. Influence of stocking density or group size on behaviour of fattening rabbit kept under intensive conditions. Applied Anim. Behav. Sci., 54, 351-357.

OUHAYOUN J., Dalle ZotTE A., 1996. Harmonization of muscle and meat criteria in rabbit meat research. World Rabbit Sci., 4, 211-218.

ROMMERS J., MEIJERHOF R., 1988. Effect of group size on performance, bone streght and skin lesions of meat rabbit housed under commercial conditions. World Rabbit Sci., 6, 299-302.

SAS, 1989. SAS ${ }^{\otimes}$ User's Guide: SAS Statistics Version 5 ed., $S A S$ Inst. Inc.; Cary, NC, USA. 